\title{
Assessment and Evaluation of the Major Ruminant Feed Resources in Bedele Woreda, Oromia, Ethiopia
}

\author{
Gebremeskel G and Solomon D \\ Jimma University College of Agriculture and Veterinary Medicine
}

\begin{abstract}
The study was conducted to assess the available feed resource in Bedele district and evaluate the nutritional quality of the major ruminant feeds. Semi-structured and pre-tested questionnaire was used in data collection on the available feed resource. . Representative samples of feed resources commonly used in ruminant animal feeding in the study area during the months of December- February were collected monthly and subjected to laboratory chemical analysis. All the data collected were analysed using Statistical Package for Social Sciences (SPSS) (version 20). The results obtained indicated that natural pasture and crop residue were the major basal diets in the study area, during the study period. The highest crude protein of $13.44 \%$ was recorded from brewery by product and the lowest (1.17\%) from maize stover. The highest fibre contents of 78.2 and $80.03 \%$ were recorded from teff straw and maize stover respectively. The total livestock population and annual feed dry matter yield of the study area was estimated to be about 715.01 TUL and 1198.41 tons respectively. The annual total crude protein yield of the study area was estimated at 0.55 tons. At an estimated annual dry matter and crude protein requirement of 1630.23 and 17.87 tons, there is negative dry matter ( 481.81 tons) and Crude protein ( 17.32 tons) balance in the study area. The annual metabolisable energy yield of the study area was estimated to be about $0.53 \%$ of the annual requirement indicating that strategic supplementation with protein and energy concentrate during the study area is appealing.
\end{abstract}

Keywords: Ruminant, Feed Resources, Nutritional Quality, Bedele Wereda.

DOI: $10.7176 / \mathrm{JBAH} / 10-7-04$

Publication date: April $30^{\text {th }} 2020$

\section{Introduction}

In Ethiopia, inadequate nutrition is one of the major constraints to increased animal production (Sere et al., 2008). Animal are fed on poorly managed and overgrazed natural pastures, subjected to seasonal variation in availability and nutritional value (Alemayehu and Sisay, 2013). On the top of grazing, ruminant animals are fed on poor quality roughages, low in protein, energy and micronutrients. In some parts of the country there is addition of foliage from tree species into animal feed aimed at provision of nitrogen to rumen microbes during dry period. Bedele Zone of f Oromia Regional State is not exception to this situation. The available ruminant feed resources, their nutritional quality and feeding practices in Bedele Wereda are not studied and documented. Moreover, improved animal feeding practices and their respective biological, social and economic feasibility to be adopted by smallholder farmers have not been tested in the Wereda. Information on the quantity of available feed resource, degree and method of utilization and nutritional contents of the available feed resources are important for the purpose of developing appropriate intervention measures. . This being the cases the measure objective of this research project was to assess the major ruminant feed resource and evaluate their nutritional content and adequacy of the feed resource in terms of the nutrient requirement of the available animal in Bedele Wereda of Oromia Regional State.

\section{Materials and Methods \\ Description of the Study Area}

The study was conducted in Bedele Wereda (district), Ilu Aba Bora Zone of the Oromia Regional State located at $483 \mathrm{~km}$ South West of Addis Ababa. Bedele town has a longitude and latitude of $8^{\circ} 27^{\prime} \mathrm{N} 36^{\circ} 21^{\prime} \mathrm{E}$ with an elevation ranging between 2,012 and 2,162 meters above sea level (BWARDO, 2015). The farming system of the Wereda is characterized by mixed crop-livestock production system. The common crops cultivated in the Wereda are teff, sorghum, finger millet, maize, coffee and wheat. The average annual rainfall is $1000-1500 \mathrm{~mm}$ and the annual minimum and maximum temperature is $24{ }^{\circ} \mathrm{C}$ and $26{ }^{\circ} \mathrm{C}$, respectively (IPMS, 2016).

\section{Determination of Sample Size}

The district was stratified into Urban, Peri-urban and Rural Kebeles (Peasant Association). Two Kebeles from each strata were purposively selected based on ruminant animal population. Thus a total of six Kebeles were used were purposively selected for the study. This was followed by random selection of 30 households from each of the six Kebeles (Table 1) and a total of 180 households were used to collect both the primary and secondary data on the major feed resource available in the study areas. The sample size of the participating households was determined using the following formula developed by (Slovin, 1960)

$\mathrm{n}=\mathrm{N} /\left(1+\left(\mathrm{N} \times \mathrm{e}^{2}\right)\right)$ 


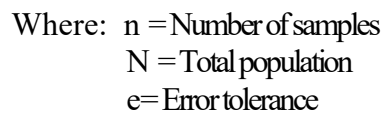

Table 1: Selection of the participating households.

\begin{tabular}{llcl}
\hline Study Areas & Kebelle/ (PA) & No. Households & Total \\
\hline Urban & Kebele 01 & 30 & \\
\multirow{4}{*}{ Peri-urban } & Kebele 02 & 30 & 60 \\
& Gema Gemeda & 30 & \\
Rural & Kolo Sirri & 30 & 60 \\
& Baashuree & 30 & 60 \\
Total & Lelistuu & 30 & 180 \\
\hline
\end{tabular}

Data Collection

Single-visit-multiple-subjects formal survey technique (ILCA 1990) was used to collect data with the use of pretested, semi-structured questionnaires prepared in local language. The primary data collected included livestock population, the amount of locally available feed resources, practice of feeding, supplementation and other related parameters. Secondary data was collected from the District and Zonal Offices with special emphasis placed on the available feed resources in the study area including secondary data required for the estimation of annual and perennial food crops produced and their respective crop residues and by products generated as animal feed. A cross sectional visit of the study area was made for close observation of ruminant animal population and the available feed resource estimation. Focused Group Discussions (FGD) was held with elders, key informants, and development agents and district administrative officers.

\section{Estimation of Feed Resource}

The annual feed dry matter produced was calculated according to FAO 1984. A Conversion factors of 2.0, 0.5 and 0.7 tons of $\mathrm{DM} / \mathrm{ha} /$ year were used for natural pasture, aftermath grazing and forest land, respectively (FAO, 1984). The annual crop residues produced was estimated by converting crop yield to straw yield in accordance Leeuw et al., (1990) and the total feed dry matter was estimated by summation of DM from the different feed sources. The total ruminant animal population of the study area was expressed in terms of total Tropical Livestock Unit, (TLU) for the purpose of comparing feed requirement and availability according to Jahnke, (1982).

\section{Feed Sample Collection and Processing}

Eight major feed types (rice bran, poultry litter, native pasture, brewers grains, dried brewery yeast, mill byproduct, and teff straw and maize stover) were selected for laboratory chemical analysis based on degree of availability and utility. Representative samples were taken from each selected feed on monthly interval during the study period of December - February. Each sample was bulked together, thoroughly mixed, air-dried and transported to Jimma University College of Agriculture and Veterinary Medicine (JUCAVM) for chemical analysis. All the feed samples were grinded to pass through $1 \mathrm{~mm}$ sieve and stored in airtight containers until required for chemical analysis.

\section{Chemical Analysis}

Dry Matter (DM), Crude Protein (CP), Ether Extract (EE), Total Ash and Nitrogen Free Extracts (NFE) contents were analyzed according to AOAC (1990). The organic matter (OM) was calculated as difference between 100 DM and ash content. Crude fiber (CF) was determined according to Van Soest and Robertson, (1985). Metabolizable Energy (ME) content was estimated using the following equations developed by Pauzenga (1985 to old).

$\% \mathrm{ME}(\mathrm{MJ} / \mathrm{kg} \mathrm{DM})=36 * \% \mathrm{CP}+81.8 * \% \mathrm{EE}+35.5 * \% \mathrm{NFE}$

\section{Statistical Analysis}

All the data collected were organized with the use of MS-Excels (2007) and analyzed using Statistical Package for Social Sciences (SPSS) (version 20). Descriptive statistics such as means, percentages, standard error of mean and frequency distribution was employed to present the data obtained from the household survey.

\section{RESULTS AND DISCUSSION}

\section{Ruminant Feed Resources and Feeding Practice}

The results obtained showed that natural pasture and crop residue is quantitatively important ruminant feed in the study area during wet and dry period respectively. Rhodes and elephant grasses and fodder trees such as Sesbania, Leuceana and tree Lucerne were found to be widely available in Bedele Wereda. The majority (76.7\%) of the 
respondents indicated fodder trees more prominent in the rural than in the urban and peri-urban areas of the woreda. On the contrary, the practice of hay making was found to be common in the urban and peri-urban than in rural areas.

All the respondents of the rural areas noted that, Brewery by products (Brewers grains and spent yeast) generated by Bedele brewery represent the major feed resources used in the urban areas. The use of supplemental feeds was reported to be rare in both rural and peri urban areas whereas it was widely practiced in urban Kebeles, possibly attributed to accessibility and awareness on the role of supplementation. Feed availability (except the brewery by-products) is subjected to seasonal variations (Table 2) in all the study areas and all the respondents indicated that feed shortage occurs in dry season (Table 9). The results obtained showed that the contribution of communal grazing land to the feed resource has generally been reduced due to increase in human population and conversion of grazing land into crop land in the rural and peri urban areas. Similar reports had been reported by Zinash Worku (2015) and Belay et al., (2015) from a survey conducted in Sekota District and Jimma town respectively.

Table 2. Availability and seasonal variation of major feed resource in the study area

\begin{tabular}{lllllll}
\hline \multirow{2}{*}{ Types of feed } & \multicolumn{5}{c}{ Season } \\
\cline { 2 - 7 } & Urban & Peri urban & Rural & Urban & Peri urban & Rural \\
\hline Natural pasture & $\mathrm{X}$ & $\mathrm{Xx}$ & $\mathrm{Xx}$ & $\mathrm{X}$ & $\mathrm{X}$ & $\mathrm{X}$ \\
Fodder trees & - & $\mathrm{X}$ & $\mathrm{Xx}$ & $\mathrm{X}$ & $\mathrm{X}$ & $\mathrm{X}$ \\
Standing hay & - & $\mathrm{X}$ & $\mathrm{X}$ & - & $\mathrm{X}$ & $\mathrm{X}$ \\
Hay & $\mathrm{X}$ & $\mathrm{X}$ & $\mathrm{X}$ & $\mathrm{Xx}$ & $\mathrm{X}$ & $\mathrm{X}$ \\
Stubble grazing & - & $\mathrm{X}$ & $\mathrm{X}$ & - & $\mathrm{X}$ & $\mathrm{X}$ \\
Crop-residue & - & $\mathrm{X}$ & $\mathrm{X}$ & $\mathrm{X}$ & $\mathrm{X}$ & $\mathrm{X}$ \\
By-products & $\mathrm{Xx}$ & $\mathrm{X}$ & - & $\mathrm{Xx}$ & $\mathrm{X}$ & $\mathrm{X}$ \\
\hline
\end{tabular}

$\mathrm{X}=$ fair availability of feed, $\mathrm{xx}=$ good availability of feed and-poor availability of feed.

\section{Feeding Practices}

Ruminant animal feeding system in the study area are shown in Fig 2) About $70.3 \%$ of the urban respondents reported to have used individual and indoor feeding (confined in the house) system with the use of industrial byproduct including by-products from local milling. According to 87.65 and $72.76 \%$ of the respondent of peri-urban and rural areas, their feeding system is dominantly based on grazing. On the contrary about $62.75 \%$ of the respondents of peri-urban areas reported to have employed tethering system of ruminant animal feeding.

About $91.67 \%$ of the respondent, indicated that supplemental feeding with the mix of table salt and atella (by-product of traditional beer) is common in urban kebeles, but occasional in peri urban and rural areas. Purchased concentrates and industrial brewers grains are the major source of supplementary feed source in urban and peri urban Kebeles. Supplementary feeds are not at the reach of rural areas, mainly due to high market price, inaccessibility and limitations in transportation. Milking cows are given priority in receiving supplementations. About $78.3 \%$ of the respondents of rural and peri urban areas reported to have used browse trees as feed during the time of feed shortage. About $48.3 \%$ of the respondents of peri-urban areas reported to have purchased mill by products to be used as supplementary feed in combination with brewers' grain during the severe dry period. About $85 \%$ of the respondents reported to have experienced feed shortages during dry seasons. The adopted dry season feed shortage were reported to include increasing the use of agro-industrial by-products, concentrate mix, conserved hay, purchased green feeds and reduction herd size. The first three strategies were common in urban areas whereas reduction in herd size either though selling or giving to relatives on temporary bases is the common practice in rural and peri urban areas. The results of this study was in agreement with that of Belay et al., (2015) who reported similar results from the survey conducted in Jimma town.

Improved forages were not common in the study area, attributed to land shortage. About $22.2 \%$ of the respondents reported to have practiced planting forage trees in the vicinity of family dwellings. According to $87 \%$ of the respondents of rural areas, there is lack of awareness on the advantage of the use of forage trees as animal feed.

The major crop residues used as livestock feed in the study area comes from maize, teff, barley, millet, sorghum and pulses. Almost all the respondents of urban kebeles reported to have store crop residue and hay under a shade by stacking. In rural and peri urban kebeles maize and teff straw are baled as dry period feed, fed after chopping (mainly for maize), treating with salt and mixing with the by-product of local brewers grains (attela). During dry period unherded grazing system is practiced, while paddock and tethering animals are common during wet season in rural and peri urban areas. On the contrary zero grazing was reported to be the most commonly used feeding system in urban areas.

The results of the study also indicated that leaves of browse trees are traditionally used as animal feed during 
period in peri urban and rural areas. The most common browse tree in the study area included Vernonia Amygdalina, Acacia Species), Pygeum Africana), Strychnos Henningsi, and Entada Abyssinica. According to $68.3 \%$ of the the respondents of peri urban and rural areas leaves of browse trees and shrubs are offered either suspended on other trees (lopped down), holding by hand or by putting on the ground.

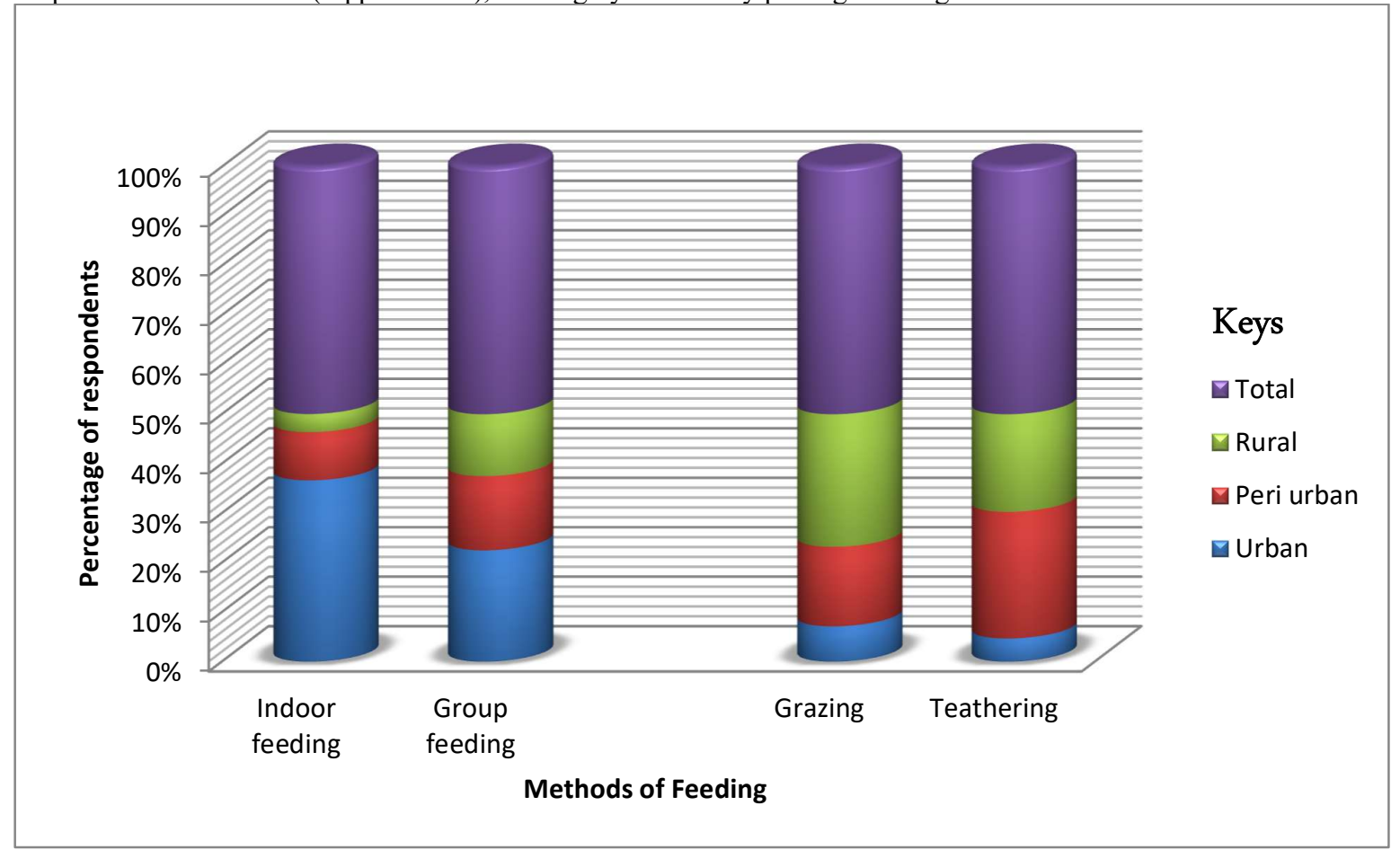

Figure 1: Methods of livestock feeding.

\section{Purchasing and Selling of Ruminant Feed}

About $76.67 \%$ of the respondents indicated that animal feed could be sold and purchased in Bedele wereda. There is practice of renting pasture land from rural farmers to be used for grazing and hay making. The tradition of hay making is not widely practiced in rural areas. About $96 \%$ respondents of the urban area, indicated that there are possibility of purchasing natural pasture from school compounds, church yards and other public holdings. Urban respondents reported to have purchased standing pasture before cutting or harvesting based on area coverage.

About $72 \%$ and $75 \%$ of the respondents of peri-urban and rural areas, reported to have their own natural pasture land for hay preparation respectively. Urban and peri urban farmers also indicated to have purchased crop residue (straw) from rural farmers. Brewery by products (brewer's grain and yeast) is the most widely sold animal feed in urban areas. Brewery by-product is not common in the rural areas since it is high in moisture content, perishable and difficult for transportation and storage. Industrial brewer's grains are commonly fed in combination with table salt. "Atella" is name of by-product of traditional brewing of beer (Tella) and distilling of alcohol (Katikala). Both Atella and poultry litter (from poultry farm) are salable and widely used animal feed resource in urban area of the study area.

\section{Farmers' perceived ranking of feed resources}

The results of the farmer's perceived ranking of feed resource are shown in Table 10. According to the respondents, grazing natural pasture and crop residues was ranked as the first and second most important feed resource respectively. The respondents ranked conserved hay of native grasses and legumes as the third most important feed resource in the dry seasons. Industrial by product obtained from Bedele brewery factory (brewery grains and spent yeast) were the forth important and widely used feed resource in the study area. Non-conventional feed such as sugar cane tops, khat (Catha edulis) leaf, banana and enset leaves and atella had the lowest ranking by the farming community. 
Table 3: Major feed resources as ranked by farmers.

\begin{tabular}{lllllll}
\hline Feed resources & \multicolumn{6}{l}{ Ranked (Number of responses) } \\
\hline & Rank 1 & Rank 2 & Rank 3 & Rank 4 & Rank 5 & (Rank) mean index \\
Grazing & 98 & 47 & 20 & 15 & 12 & $0.289(1)$ \\
Hay & 12 & 27 & 78 & 22 & 37 & $0.177(4)$ \\
Crop residue & 20 & 76 & 40 & 31 & 9 & $0.220(2)$ \\
I. by-product & 50 & 30 & 33 & 20 & 25 & $0.198(3)$ \\
N.C. feed & - & - & 12 & 92 & 97 & $0.117(5)$ \\
Total & 180 & 180 & 180 & 180 & 180 & 1.00 \\
\hline
\end{tabular}

Index $=\left[\left(5 \times\right.\right.$ number of responses for $1^{\text {st }}$ rank $+4 \times$ number of responses for $2^{\text {nd }}$ rank $+3 \times$ number of responses for $3^{\text {rd }}$ rank $+2 \times$ number of responses for $4^{\text {th }}$ rank $+1 \times$ number of responses for $5^{\text {th }}$ rank $\left.)\right]$ divided by $(5 \times$ total responses for $1^{\text {st }}$ rank $+4 \times$ total responses for $2^{\text {nd }}$ rank $+3 \times$ total responses for $3^{\text {rd }}$ rank $+2 \times$ total responses for $4^{\text {th }}$ rank $+5 \times$ total responses for $5^{\text {th }}$ rank)

\section{Estimated Annual Feed Availability}

A total of 1198.41tons of feed dry matter was calculated to be produced/year at the study areas (Fig 2). About $77.41,12.52,6.1,2.7$ and $1.1 \%$ of the total annual feed dry matter comes from crop residue, natural pasture, after math grazing, forest land and fallow land respectively. About 49 and $29.5 \%$ of the total annual crop residue was calculated to be obtained from maize and sorghum straws, Variation of DM yield obtained from crop residue might be attributed to the difference, amount and types of food crop cultivated in the district. The total DM obtained from natural pasture in the current study was lower than that reported by Yadessa et. al from Meta Robi district but higher than that reported by Zinash from Sekota district. The proportion of crop residues used as animal feed was higher as compared to the other feed types in the study district. The result of this study was in agreement with that of Yeshitila et al. (2008) and Yadessa et al., (2016) who reported that crop residues accounted for 78.72 and $76.2 \%$ of the total annual dry matter yield in most parts of the country respectively.

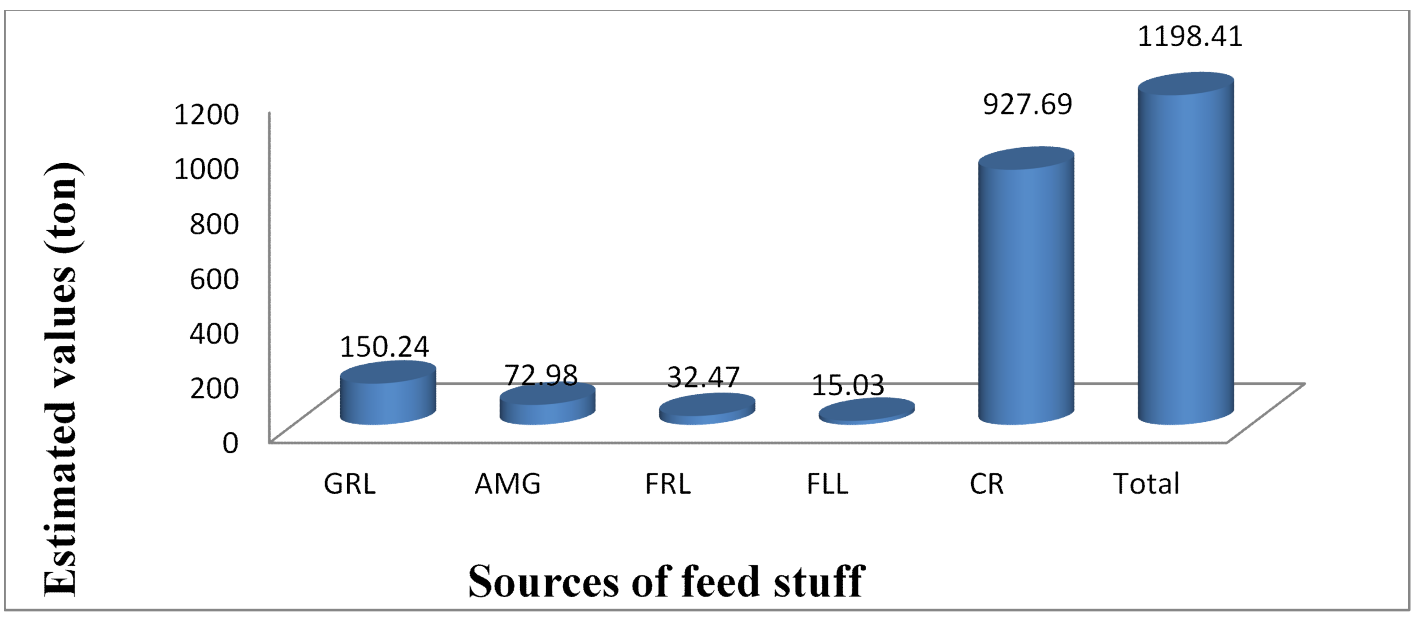

Figure 2: Total DM production shares of different feed stuffs in selected kebeles

$\mathrm{GRL}=$ Grazing land resource, $\mathrm{AMG}=$ Aftermath grazing, $\mathrm{LRL}=$ Forest land, $\mathrm{FLL}=$ Fallow land, $\mathrm{CR}=\mathrm{Crop}$ residue.

\section{Ruminant Feed and Nutrient Balance}

The total ruminant livestock population of the study area was estimated to be about 715.01 TLU. . The dry matter requirement of the ruminant population of the study area was also estimated at 1630.23 tons per annum.. According to Fig.2, the total annual dry matter production of the study area was calculated at 1198.41 ton of feed dry matter indicating that the total feed dry matter yield of the study area was about $73.5 \%$ of the dry matter requirement of the ruminant animal population. The annual dry matter requirement of ruminant animal population of urban. Periurban and rural areas of the study district was 417.1, 547.18 and rural 665.94tons respectively, indicating the feed dry matter requirement of rural areas was higher than the others attributed to the relatively large number of livestock population in the rural areas. 0913306797 briuk $A$ total of 0.55 and 42.71 tons of crude proteins metabolizable energy was calculated to be produced annually in the study areas. As compared to 17.87 and 2183.87 tons crude protein and metabolizable energy calculated as requirement of the available ruminant animal population of the study area, indicating negative crude protein and energy balance of -17.32 and -2141.16 
tons/annum respectively (Fig 3).

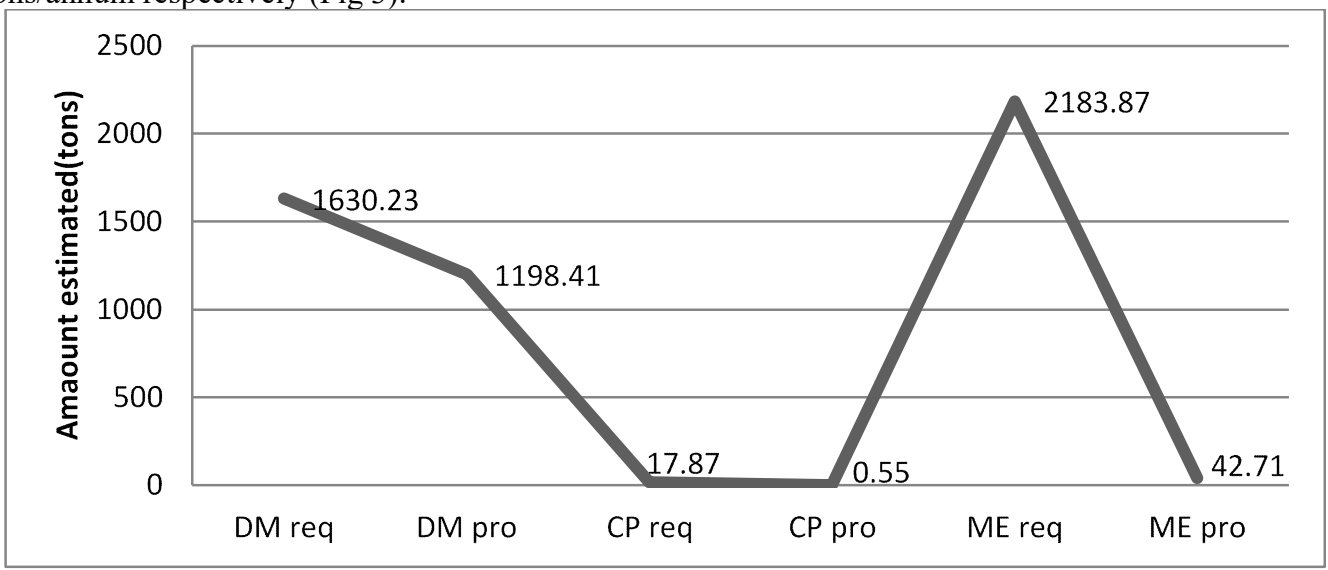

Figure 3: Estimated balance between nutrient supply and requirement for TLU.

(DM, dry matter; $\mathrm{CP}$, crude protein; ME, metabolisable energy; req, requirement ; pro, produced)

\section{Chemical Composition of Selected Feeds}

Chemical composition and estimated metabolizable energy contents of selected feeds commonly used in the study area are given in Table 9. The feeds subjected to laboratory chemical analysis and estimation of energy value included rice bran, poultry litter, grass hay, brewers grains, dried brewery yeast, mill by product, teff straw and maize stover (Table 4). The general tendency is that the chemical composition of feed varies based on harvesting time, agro climatic conditions, cultural practices and post-harvest processing and storage conditions. (Bittante and Andrightto, 1982). The dry matter content of the selected feed material ranged from $90.12-95.59 \%$. Percentage composition of ash of dried brewery yeast $(27.08 \%)$ and maize stover $(3.16 \%)$. was the highest and lowest respectively. Brewer's yeast had the highest crude protein content (17.7\%) followed by dried brewer grain $(13.44 \%)$ indicating that brewery by-product could be used as protein supplementary protein concentrate in the study area. With the exception of poultry litter, the crude protein content of all the other feeds was lower than that set as a minimum level of nitrogen (7\%) required to limits intake (Milford and Minson, 1966; Van Soest, 1982). The crude protein content of rice bran, mill by product and grass hay was also found to be less than the optimum crude protein requirement for maintenance of ruminant animal. The crude fibre content of all the crop residues analysed was above $65 \%$. Roughage with a fibre content of less than 45.45 to 65 and higher than $65 \%$ are categorized as high, medium and low quality feeds respectively (Singh and Oosting, 1992). The crop residues analysed in the current study could be categorized as low quality roughages that may inflict limitations on animal performance. The fiber content of grass hay $(65.49 \%)$, teff straw $(78.2 \%)$ and maize stover $(80.03 \%)$, all the values of which were higher than $65 \%$ are low quality roughage feeds. Dried brewery yeast and mill by product had the lowest crude fibre content (28.5- 39.2\%) are categorized as high quality feed. Rice bran (46.19\%), poultry litter (48.25\%) and brewer's grains (63.2\%) were categorized as medium quality feed resource. Low metabolizable energy values $(1.27-2.28 \mathrm{MJ} / \mathrm{kg})$ was recorded from maize stover and grass hay and might require chemical treatment as suggested by Owen and Jayasuriya, (1989). Brewery grains, rice bran and dried brewery yeast had the highest energy content ranging between 7 and $1212 \mathrm{MJ} / \mathrm{kg}$. . The difference in metabolizeable energy content of the feedstuffs studied reflects the different contents of fermentable carbohydrates and available nitrogen.

Table 5: Composition and nutritive value of selected feeds in the study area.

\begin{tabular}{llllllll}
\hline Feed stuff & \multicolumn{8}{c}{ Chemical composition (\%DM) } & Nutritive Value \\
\hline & DM & Ash & OM & CF & EE & CP & ME* \\
Rice bran & 92.4 & 24.09 & 75.91 & 46.19 & 11.45 & 6.015 & 11.91 \\
Poultry litter & 90.79 & 17.33 & 82.67 & 48.25 & 0.82 & 11.045 & 5.34 \\
Grass hay & 93.77 & 11.06 & 88.94 & 65.49 & 1.22 & 3.07 & 2.28 \\
Brewery yeast & 90.12 & 27.08 & 72.92 & 28.5 & 0.7 & 17.7 & 7.99 \\
Mill by product & 90.23 & 18.78 & 81.22 & 39.2 & 3.75 & 6.65 & 5.88 \\
Brewers grains & 92.2 & 22.62 & 77.38 & 63.2 & 8.26 & 13.44 & 12.43 \\
Teff straw & 93.35 & 9.81 & 90.19 & 78.2 & 1.62 & 7.004 & 4.24 \\
Maize stover & 95.59 & 3.16 & 96.84 & 80.03 & 0.73 & 1.17 & 1.27 \\
\hline
\end{tabular}

$\mathrm{ME}^{*}=$ Metabolisable Energy MJ/kg DM 


\section{SUMMARY AND CONCLUSION}

The major feed resource of the study area consists of crop residues, natural pastures, hay, fodder trees, and brewers by products. The study area was characterized by negative crude protein (27.45 tons) and metabolizable energy (63.52 MJ) balance annually. .

The Crude protein contents of the available feeds range from 1.17 to $17.7 \%$. Brewer's yeast, brewery grains and poultry litter with crude protein content of $11-17.7 \%$ represented feeds with fairly higher protein in the study area. . The relatively lower protein content of the feeds of the study area might be due an extended storage, low rate of nitrogen fertilizers application, stage of harvesting and processing and storage conditions. The lower crude protein contents of the feed resource of the study area could be compensated through the use of supplementary protein concentrate. The general tendency seems to indicate that the number of livestock and the available feed resources do not match to support profitable livestock production in the study areas. The primary focus needs to be improving both the quantity and quality of the existing feed resources.

\section{RECOMMENDATION}

$>$ To study into the feasibility of providing strategic supplementation of protein and energy concentrates on the top of improving the current practice of utilization of brewery by-product and poultry litter both of which are widely available in the study area. .

$>$ Practicing simple and better degree of feed conservation such as hay making to cope up with the critical feed shortage during the dry period.

$>$ Awareness creation through the local agricultural extension structure on the role of feed conservation and strategic supplementation aimed at correction of critical nutrient deficiencies.

\section{REFERANCES}

Alemayehu Mengistu and Sisay Amare, 2013. Integrated Livestock Development and Project (ILDP). Livestock Feed Resources survey, North Gondar, Ethiopia. pp. 75

AOAC (Association of Official Analytical Chemists) 1990.Official methods of analysis.13 ${ }^{\text {th }}$ edition. AOAC, Washington DC, USA. Tropical and Subtropical Agroecosystems, 17 (2014): 539 - 546545

Belay Duguma and Geert Paul Jules Janssens 2015. Assessment of feed resources, feeding practices and coping strategies to feed scarcity by smallholder urban dairy producers in Jimma town, Ethiopia

BWARDO (Bedele Wereda of Agriculture and Rural Development office), 2016. Annual report, Ilu Aba Bora zone, Ethiopia

Chalchissa, Girma; Mekasha, Yoseph; and Urge, Mengistu. 2014 Feed Resources Quality and Feeding Practices in Urban and Peri-Urban Dairy Production of Southern Ethiopia

CSA (Central Statistical Agency), 2014.Agricultural Sample Survey 2013/14.Report on Livestock and Livestock Characteristics, Volume II, Statistical Bulletin, 532. Addis Ababa, Ethiopia.

De Leeuw, P.N. and J.C. Tothill, 1990. The concept of rangeland carrying capacity in Sub- Saharan Africa-myth or reality. Pastoral Development Network Paper. Overseas Development Institute, London.

Endale Yadessa, Abule Ebro, Lemma Fita and Getnet Asefa (2016) Livestock feed production and feed balance in meta Robi District, West Shewa Zone, Oromiya Regional State, Ethiopia

E. Owen, R.F.E. Axford\& H.M. Ohmed, eds. Forage evaluation in ruminant nutrition, pp. 281300. CABI Publishing, Wallingford, UK.

FAO (Food and Agriculture Organization of the United Nations), 1984. Assistance to land use planning in Ethiopia. Livestock production and feed resources. UNDO/AO, Technical report 6.

ILCA (International Livestock Center for Africa). (1990) Livestock systems research manual.No.12, section 1.Working document, Addis Ababa, Ethiopia.

Jahnke, H. E., 1982. Livestock Production Systems and Livestock Development in Tropical Africa. Kieler Wissenschaftsverlag Vauk. Kiel, Germany.

Kossila, V. 1984. Location and potential feed use. In: Sundstøl, F. and Owen, E. (Eds.). pp. 4- 24

Milford, R. And D.J.Minson, 1966. The relation between the crude protein content and the digestible crude protein of tropical pasture plants. J. Br. Grassl. Society, 20: 177-183.

Pauzenga, U (1985) Feeding Parent Stock. Zootecnica International Pp 22-24 The state of Queensland (Department of Agriculture and Fisheries) 2010-2015.

Sere C, Ayantunde A, Duncan A, Freeman A, Herrero M, Tarawali S and Wright I 2008Livestock production and poverty alleviation-challenges and opportunities in arid and semi-arid tropical rangeland based systems.

Singh and Oosting, 1992. A study of forage yield and nutritive value of natural pastures at varying levels of maturity in North West Lowlands of Ethiopia

Slovin, 1960. Presents a formula to determine the size of a sample $\left(n=N /\left(1+\mathrm{Ne}^{2}\right)\right.$

Van Soest, P.J., J.B.Robertson and B.A. Lewis. 1991. Methods of dietary fiber, neutral T fiber and nonstarch carbohydrates in relation to animal nutrition. J. Dairy Sci. 
Winrock International Institute for Agricultural 1992. Assesement of Agricuture in Sub-Saharan Africa. Winrock: Morrilton, Arkansaa

Yeshitila Admassu. 2008. Assessment of Livestock Feed Resources Utilization in alaba woreda,.Southern Ethiopia, M.Sc. Thesis Haramaya University. Haramaya, Ethiopia.

Zinash worku 2015. Assessment of livestock production practices and feed resources in peri urban and rural arseas in waghimra zone sekota district, ethiopia. a thesis submitted to the, school of animal and range sciences postgraduate program directorate Haramaya university 